\title{
СИНТЕЗ КОМПОНЕНТОВ ФЕРОМОНОВ ЩЕЛКУНА КУБАНСКОГО И КАЛИФОРНИЙСКОЙ ЩИТОВКИ
}

\author{
K. SIIRDE, A. ERM, Signe TENG, K. LAATS. KUBANI NAKSURI JA KALIFORNIA KILPTAI \\ FEROMOONIDE KOMPONENTIDE SUNTEES \\ K. SIIRDE, A. ERM, Signe TENG, K. LAATS. SYNTHESIS OF CUBAN CLICK BEETLE AND SAN \\ JOSE SCALE PHEROMONE COMPONENTS
}

В определенных условиях электрофильное присоединение $\mathrm{Cl}_{2}$ [1], $\mathrm{HOCl}\left[{ }^{2}\right], \mathrm{ClOC}\left(\mathrm{CH}_{3}\right)_{3}\left[{ }^{3}\right]$ по двойным связям изоалкенов приводит $\mathrm{K}$ образованию монохлоридов аллильного строения, представляющих интерес в качестве удобных синтонов. В настоящей работе использована $\mathrm{HOCl}$ для получения аллильных хлоридов из геранилизовалериата, геранилпропионата и нерилпропионата с целью синтеза компонента феромона щелкуна кубанского (Agriotes litigiosus Rossi) 2,6-диметит-2( $E^{\prime}$, $6(E)$-октадиен-1,8-ди- (3-метилбутаноата) (I) $\left[{ }^{4}\right]$ и компонентов феромона калифорнийской щитовки (Quadraspidiotus perniciosus Comst.) 3,7-диметил-2 $(E), 7$-октадиенилпропионата (II) и 3,7-диметил-2(Z),7-октадиенилпропионата (III) [5] по схеме:

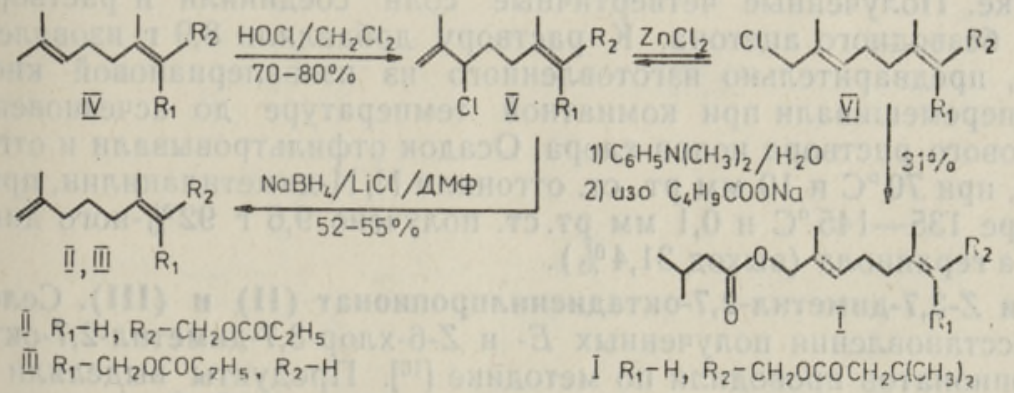

Исходные сложные эфиры (IV) гераниола и нерола, синтезированные из теломера изопрена с его моногидрохлоридами, имели чистоту $97-99 \%$ [6]. В первой стадии синтеза получены 6-хлорпроизводные терпеновых сложных эфиров, при этом HOCl генерировали из гипохлорита натрия [ $\left.{ }^{2}\right]$. Полученный 6-хлорпроизводный геранилизовалериата переводили в первичный аллильный хлорид, который выделяли в виде водорастворимой аммониевой соли с N,N-диметиланилином $[7,8]$. В ходе дальнейшего алкилирования изовалериата натрия получен диизовалериат гераниола (I) [9]. Для получения компонентов феромона калифорнийской щитовки (II) и (III) 6-хлорпроизводные геранил- и нерилпропионатов восстанавливали боргидридом натрия [ $\left.{ }^{10}\right]$. 
ГЖХ проводили на хроматографе «Цвет 6-69A» с ПИД; колонка стеклянная капиллярная $47000 \times 0,3$ мм с нанесенным PDEAS; температура испарителя $270^{\circ} \mathrm{C}$, колонки 120,150 и $165^{\circ} \mathrm{C}$; скорость газа-носителя (аргона) 2,0 мл/мин.

Структуры соединений (I-III) подтверждены методом ЯМР ${ }^{13} \mathrm{C}$. Химические сдвиги приведенных соединений хорошо совпадают с ранее полученными для аналогичных соединений [6, 10,11].

Производные 6-хлор-3,7-диметил-2,7-октадиена (V). Через реакционную смесь, состоящую из 25,0 г монотерпенового сложного эфира (IV), 500 мл хлористого метилена (большой объем растворителя необходим для предотвращения образования хлоргидринов) и 85 мл раствора $\mathrm{NaOCl}$ (с 95 г/л активного хлора), при перемешивании пропускали $\mathrm{CO}_{2}$, поддерживая температуру $0^{\circ} \mathrm{C}$. Окончание реакции определяли по данным ГЖХ-анализа реакционной смеси (по исчезновению пика исходного (IV)). После отстаивания слой органики сушили над сульфатом магния. Хлористый метилен отгоняли. Из геранилпропионата получено 27,9 г продукта с содержанием (V) $80 \%$ (выход 79\%), из нерилпропионата 26,7 г продукта с содержанием (V) $75 \%$ (выход $71 \%$ ) и 27,8 г из геранилизовалериата с содержанием (V) $81 \%$ (выход $80 \%$ ).

2,6-Диметил-2 $(E), 6(E)$-октадиен-1,8-ди-(3-метилбутаноат) (I). Для изомеризации к 27,8 г 6-хлор-3,7-диметил-2 $(E), 7$-октадиен-1-(3-метилбутаноата) добавляли 0,7 г $38 \%$-ного раствора $\mathrm{ZnCl}_{2}$ в изопропаноле. По данным ГЖХ-анализа, образовавшаяся в течение 5 суток при комнатной температуре равновесная смесь содержала $36 \%$ вторичного и $27 \%$ первичного хлорида. К полученной смеси добавляли 4,0 г N, N-диметиланилина, 4,0 г $\mathrm{CH}_{3} \mathrm{OH}$ и выдерживали 12 ч. Образовавшуюся из первичного хлорида четвертичную аммониевую соль с N,N-диметиланилином экстрагировали из смеси водой, промывали петролейным эфиром, насыщали поташом и сушили азеотропной отгонкой воды с толуолом (200 г) в вакууме при 60 мм рт. ст. (темп. бани не выше $45^{\circ} \mathrm{C}$ ). Остаточный вторичный хлорид подвергали повторной обработке с $\mathrm{ZnCl}_{2}$ по приведенной методике. Полученные четвертичные соли соединяли и растворяли в 100 мл безводного ацетона. К раствору добавляли 8,9 г изовалериата натрия, предварительно изготовленного из изовалериановой кислоты. Смесь перемешивали при комнатной температуре до исчезновения из ацетонового раствора ионов хлора. Осадок отфильтровывали и отгоняли ацетон, при $70^{\circ} \mathrm{C}$ и 10 мм рт. ст. отгоняли $\mathrm{N}, \mathrm{N}$-диметиланилин, при температуре $135-145^{\circ} \mathrm{C}$ и 0,1 мм рт. ст. получено 9,6 г $92 \%$-ного диизовалериата гераниола (выход $31,4 \%$ ).

$E$ - и Z-3,7-диметил-2,7-октадиенилпропионат (II) и (III). Селективные восстановления полученных $E$ - и $Z$-6-хлор-3,7-диметил-2,7-октадиенилпропионатов проводили по методике [10]. Продукты выделяли перегонкой. Получили 11,4 г $91 \%$-ного 3,7-диметил-2 $(E), 7$-октадиенилпропионата (т. кип. $95-97^{\circ} \mathrm{C}$ при 2 мм рт. ст., выход $55 \%$ ) и 10,1 г $89 \%$-ного 3,7 -диметил-2 $(Z), 7$-октадиенилпропионата (т. кип. $97-99^{\circ} \mathrm{C}$ при 2,5 мм рт. ст., выход $52 \%$ ).

Авторы выражают благодарность Т. Вялимяэ за ЯМР ${ }^{13} \mathrm{C}$-анализ.

\section{Л ИТЕ РАТ У РА}

1. Мукс Э. Сопоставление реакций электрофильного присоединения. Конкурирующие направления, определяемые строеннем алкена. - Изв. АН ЭССР. Хим., 1987, 36 , № 2, 103-113.

2. Hegde, S. G., Vogel, M. K., Saddler, J., Hrinyo, T., Rackwell, N., Haynes, R., Oliver, M., Wolinsky, J. The reaction of hypochlorous acid with olefins. A convenient synthesis of allylic chlorides. - Tetrahedron Lett., 1980, 21, № 5, 441-444. 
3. Sato, W., Ikeda, N., Yamamoto, H. An efficient double bond chlorination of olefins by tert-butyl hypochlorite. - Chem. Lett., 1982, № 1, 141-142.

4. Исмаилов В. Я., Олещенко И. Н., Орлов В. Н., Алексеенко А. В. Новый подход к регулированию численности с помощью синтетических половых феромонов. В кн.: Химическая коммуникация животных. М., 1986, 109-112.

5. Лебедева К. В., Миняйло В. А., Пятнова Ю. Б. Феромоны насекомых. М., 1984, 84.

6. Тенг С., Вялимяэ T., Лээтс $K$. Сложные эфиры гераниола и нерола. - Изв. АН ЭССР. Хим., 1984, 33, № 1, 57-58.

7. Мукс Э., Эрм А., Кабрал С., ЛЭэтс К. Продукты хлорирования 2-метил-2-бутена. Изв. АН ЭССР. Хим., 1979, 28, № 1, 46-48.

8. Лээтс K. B. K изучению ионно-каталитической теломеризации III. О новом методе выделения первичных аллильных галоидпроизводных из смеси изомеров. Геранилхлорид. Сесквитерпеновые хлориды. - Ж. общ. хим., 1961, 31, № 6, $1869-1876$.

9. Лээтс К. В. Способ получения сложных эфиров замещенных первичных аллиловых спиртов. - Открытия, изобретения, 1960, № 14, авт. свид. СССР № 130042.

10. Novak, L., Poppe, L., Szantoy, C. A facile synthesis of two isomeric components of San Jose scale pheromone. - Synthesis, 1985, № 10, 939-941.

11. Тенг C., Вялимяэ T., Лээтc K. 2,6-Диметил-2 $(E), 6(E)$-октадиен-1,8-ди-(3-метилбутаноат). - Изв. АН ЭССР. Хим., 1984, 33, № 3, 194.

\section{Институт химии \\ Академии наук Эстонской ССР}

Поступила в редакцию

3/XII 1987 